Canadian Journal of Higher Education Revue canadienne d'enseignement supérieur

Volume 43, No. 2, 2013, pages 1-26

\title{
IMAGINE: Canada as a leader in international education. How can Canada benefit from the Australian experience?
}

Roopa Desai Trilokekar and Zainab Kizilbash

York University

\begin{abstract}
Hosting international students has long been admired as one of the hallmarks of internationalization. The two major formative strands of internationalization in Canadian universities are development cooperation and international students. With reduced public funding for higher education, institutions are aggressively recruiting international students to generate additional revenue. Canada is equally interested in offering incentives for international students to stay in the country as immigrants after completing their studies. In its 2011 budget, the Canadian federal government earmarked funding for an international education strategy and, in 2010, funded Edu-Canada-the marketing unit within the Department of Education and Foreign Affairs (DFAIT) - to develop an official Canadian brand to boost educational marketing, IMAGINE: Education in/au Canada. This model emulates the Australian one, which rapidly capitalized on the recruitment of international students and became an international success story. Given current Canadian higher education policy trends, this paper will address the cautionary lessons that can be drawn from the Australian case.
\end{abstract}

\section{Résumé}

Accueillir des étudiants étrangers a longtemps été considéré comme l'une des caractéristiques principales de l'internationalisation. On considère en effet que les deux principales lignées formatrices de l'internationalisation parmi les universités canadiennes sont l'accueil d'étudiants étrangers et la coopération pour le développement. Le financement public de l'enseignement supérieur s'étant amoindri, les gouvernements et les établissements d'enseignement d'autres pays recrutent énergiquement les étudiants étrangers dans l'espoir 
de produire des revenus supplémentaires. Le Canada est tout aussi intéressé à présenter des mesures incitatives aux étudiants étrangers afin qu'ils immigrent au pays. En effet, dans son budget de 2011, le gouvernement fédéral du Canada attribuait des fonds à une stratégie d'enseignement internationale un an après avoir fondé Edu-Canada, un service de marketing au sein du ministère de l'Éducation et de celui des Affaires étrangères et du Commerce international. L'objectif d'Edu-Canada est de créer une image de marque canadienne officielle, aujourd'hui baptisée IMAGINE: Education au/in Canada, pour relancer le marketing de l'enseignement. Ce faisant, le Canada imite l'Australie, l'un des premiers pays occidentaux à rapidement tirer profit du recrutement d'étudiants étrangers pour en faire une réussite. Devant les tendances politiques actuelles en enseignement supérieur au Canada, cet article présente les leçons de prudence à tirer du cas de l'Australie.

The debate that surrounds what truly comprises the internationalization of higher education is long standing. Hosting international students has always been an important part of internationalization efforts because the value of international students has long revolved around the benefits of broader national and international goals (de Wit, 2002; Cudmore, 2005; Galway, 2000). Indeed, an internationally diverse campus has been admired as one of the hallmarks of internationalization. However, this movement has increasingly translated into the aggressive recruitment of international students in what has become a competition between several developed and emerging nations. In this paper, we compare the current trends in Canada's policy approach with the Australian model, which is generally considered to be highly successful. Specifically, we would like to assess what challenges and lessons Canada might benefit from given the Australian experience. This paper begins with some context.

\section{Brief History of International Education and International Students in Canada}

In Canada, overseas development assistance (ODA) is considered to be the foundational feature of Canadian internationalization. In the 1950s and 1960s, the two major formative strands of internationalization in Canadian universities were considered to be development cooperation and international students (Bond \& Lemasson, 1999). This is because embedded in Canada's soft power foreign policy was an acknowledgment of Canada as an anti-imperial power committed to supporting a just and equitable world order. A direct result of this policy approach was the arrival of international students to Canada from developing countries as part of the Colombo Plan (1950), the Commonwealth Scholarship and Fellowship Plan (1960), and several Canadian International Development Agency (CIDA) sponsored development projects (Shute, 1999). Between 1964 and 1976, however, there was a dramatic shift in Canadian development policy that resulted in severe budget cuts in the late 1970s. These budget cuts altered CIDA's role in the university sector and directly resulted in a decline of international students on Canadian campuses (Pratt, 1996).

The discussion of international students on Canadian campuses was introduced once again in the mid 1980 s with the Commission on Canadian Studies' 1984 publication, 
"Some Questions of Balance: Human Resources, Higher Education and Canadian Studies." A whole chapter of this report was dedicated to discussing international students in Canada and the policy vacuum surrounding them. While lamenting that neither the government nor academic institutions had come to grips with the issue, the report recommended that the federal government take lead in this policy area. The Commission laid out a set of 24 recommendations to develop a national foreign student policy and establish a new national agency, the Council on Foreign Student Policy and Programs. It was one of the first reports that recommended a full fee-paying model for foreign students studying in Canada to replace the existing policy that allowed for approximately $\$ 300$ million in Canadian tax dollars to be spent on the education of roughly 35,000 foreign students studying at Canadian universities in 1982-83. Simultaneously, the report recommended that these students be allowed to work during the academic year (Symons, 1984). Although the Department of Foreign Affairs and International Trade's (DFAIT's) Academic Division found several of these recommendations impractical (NAC, 1984), most provinces were charging differential fees to international students in Canada by 1986 . The recommended Council on Foreign Student Policy and Programs was never formed, however, and no national policy on foreign students was ever established.

An interest in hosting fee-paying foreign students in Canada started gaining momentum in the mid 1980 s with the first meeting of the Federal-Provincial Consultative Committee on Education-Related International Activities (FFPECERIA) (Council of Ministers of Education in Canada [CMEC], 1991). As a result of these discussions, the FFPECERIA published the policy document, "Foreign students in Canada," in 1986, which recommended full participation with the federal government and a simplification of visa procedures and processes for foreign students. On the question of developing a national policy on foreign students, CMEC did not agree that there was a policy vacuum because the provinces had already established practices and policies for the "reception of foreign students" in cooperation with institutions in their regions. CMEC did, however, suggest that there was room for better coordination of these provincial policies and practices (CMEC, 1991). In 1988, FPPECERIA began focusing more broadly on discussions regarding the marketing of Canadian education abroad and was successful in synthesizing information from the provinces regarding institutional capacity for foreign students, as well as various marketing strategies.

Beginning in the early 1990s, the Canadian government focused on the growing importance of the new "knowledge based economy" and the central role of higher education. The effective marketing of higher education and training was considered especially important for a country like Canada, which relied on exports for a third of its Gross National Product (GNP). Slowly but surely, the "trade creep" in foreign policy began encouraging economic rationales for the internationalizing of higher education (CMEC, 1991). In 1994, DFAIT published a paper titled, "The International Dimension of Higher Education in Canada: Collaborative Policy Framework," after extensive interdepartmental consultations, as well as consultations with various constituencies and the provinces. The discussion paper indicated that Canada ranked fifth among countries that received foreign students, hosting 37,000 students in 1992 with contributions to the Canadian economy estimated at C\$472 million. Once again, there was a recommendation to develop a national marketing strategy, and two conferences were hosted: an international symposium 
on North American collaboration and a national conference on international marketing of higher education. While there was support from industry, coordination with the provinces seemed challenging: "provinces are now indicating some hesitancy in an aggressive marketing strategy for post secondary international students since they are concerned about adequate space for Canadians" (DFAIT, 1991, p.8).

Regardless, the importance of marketing Canadian higher education continued to grow at the federal level, and the first formal marketing investment by the government was made in 1991 when the Asia Pacific Geographic Division opened an education office in Taiwan. Given the success of this initiative, interest grew in finding a more permanent source of funding. The Asia Pacific Branch made a request to both CIDA and DFAIT and, in 1995, an agreement was negotiated between DFAIT, CIDA, Citizenship and Immigration Canada (CIC), and the Asia Pacific Foundation of Canada (APFC), and international marketing activities were initiated through the Canadian Educational Centers (CEC), a fully owned legal entity of APFC. A five-year plan was developed and eight CEC offices were established.

Canadian institutions were, however, critical of the Canadian Educational Centers Network (CECN) funding model, which was based on the partial recovery of the centers' operating costs through subscription and service fees that the CECN collected from educational institutions. From the government's perspective, the project model stimulated an entrepreneurial approach at the very early stages of this enterprise; however, from the perspective of Canadian universities, the federal government was not fulfilling its obligations (APFC, 2008; Trilokekar, 2007). Sergio Marchi, Minister of International Trade, launched a parallel initiative, stating that education ought to be considered an industry and that Canada needed to approach the international marketplace for education services with the same discipline and commitment that it brought to other sectors (CMEC, 1998). Convinced of its importance, Marchi organized a roundtable that resulted in the creation of an educational marketing unit within the Department in September 1998, "a one stop shopping for education promotion" (Trilokekar, 2007).

Beginning in 2001, the government began to withdraw its support to the CECs and the CECN began operating as a private non-profit company. By 2004-05, the government had terminated the CECN's core funding, and, unfortunately, in June 2009 the CECN announced that it would cease all operations. In 2004, the marketing unit within the Department of Foreign Affairs, the Division of Academic Relations, was moved to the Department of Trade. When the departments were once again amalgamated as DFAIT in 2006, part of the marketing division was shifted back into academic relations (International Education and Youth), and the Edu-Canada initiative was established.

To boost educational marketing in 2007 as part of its Global Commerce Strategy, the federal budget allocated an annual amount of $\mathrm{C} \$ 1$ million to Edu-Canada to develop an Education Brand for Canada. DFAIT engaged in extensive consultations with the provincial governments and federal departments through FPCCERIA and requested input from various stakeholder groups, including the university sector (DFAIT Branding Initiative Background, 2008; Tamburri, 2008). In 2008, after 18 months of extensive consultation, "IMAGINE: Education in/au Canada" was launched as the official Canadian brand with both levels of government committed to its creation, development, and management. DFAIT and the CMEC Secretariat jointly manage the brand, and the National Education 
Marketing Roundtable (NEMR) enables communication of brand guidelines and usage between several governmental, non-governmental, and private stakeholders. While the federal government has begun using the brand, it is unclear if all 10 provinces have integrated it into their own marketing strategies and there seem to be few takers among individual public universities. As a parallel support network to strengthen Canada's educational marketing efforts, five national educational associations have come together to establish the Canadian Consortium for International Education Marketing (Media Release, 2010).

Canadian Immigration regulations concerning international students have also seen major changes in the 2000's, further supporting and aligning governmental efforts in the marketing of Canadian higher education. In 2006, the federal government launched the Off-Campus Work Program for international students in cooperation with the provinces. With the increasing reliance on immigration to meet growing labor-market needs, government policy shifted towards encouraging international students to immigrate. In 2007, it introduced the Canadian Experience Class, making it easier for international students with education and work experience in Canada to apply for permanent residency. In 2008, the Post-Graduate Work Experience Program began to further facilitate open work permits for eligible international students. In addition, Canadian embassies and consulates overseas have been streamlining their visa requirements and application processes directly reducing wait times and increasing the level of student visa approvals, especially in key markets.

The potential for international student recruitment, which had been on the federal agenda since the late 1970 or or early 1980s, received impetus in the mid 1990s and further momentum since 2000. While Canada was still unsuccessful in establishing a national policy, both levels of government supported the development of a national logo and a branding platform for marketing higher education in 2008. Perhaps one might suggest that with growing interest in the recruitment of international students and the marketing of higher education across all related stakeholder groups, "the stars are finally aligned" for Canada. The federal government's 2011 budget further reinforces this momentum, allocating $\$ 10$ million over a two-year period for the development and launch of an international education strategy and the selection of an Expert Advisory Panel for this purpose (DFAIT, 2011) ${ }^{1}$. It is in this context and with the recognition that Canada is a relative novice in this particular export industry that a comparative analysis of the Australian experience may be valuable.

International education is considered to be an Australian success story. Australia was one of the first Western nations to rapidly capitalize on the recruitment of international students and achieve an enormous level of success in attracting and sustaining the growth of very large numbers of international students, thus ensuring its stake in the "international mobility market." Australia ranks third after the U.S. and U.K. in a list of countries hosting the largest number of international students-Canada ranks seventh with a substantially lower number of enrollments. After commissioning two key reports in 2009-"Economic Impact of International Education in Canada," which quantified the economic impact of international students to Canada, and "Best Practices on Managing the Delivery of Canadian Education Marketing," which spoke to the need for Canada to coordinate its marketing efforts to attract its fair share of the international student market-DFAIT proclaimed its ambition to replace Australia as the third largest host for in- 
ternational students. How has Australia developed this export industry? How does Australia position itself in the international educational market? What strategies and policy approaches has it adopted and what successes or failures has it experienced? What can we learn from the Australian case?

\section{Australia}

Although Canada and Australia share many similarities as nations, including their membership to the British Commonwealth and their policies on multiculturalism and immigration, there are striking difference between their respective systems of higher education. Although both countries are federations, Australia has a federal ministry of education, but Canada does not. In Australia, higher education is a shared jurisdiction and receives funding from the federal government. In Canada, education is largely considered a provincial responsibility. While Australia has both a private and a public sector, Canada's higher educational system is largely public and uniform in quality. Australia has 38 public and four private universities; Canada, meanwhile, has over 95 universities. Both countries enjoy high participation rates in their post secondary sectors (Australia Education Network, 2012; AUCC, 2012).

The following observations on Australia's international education policy and strategies have been made primarily based on secondary sources, including academic articles, government reports, and various government and organizational websites. In Australia, international education is synonymous with the recruitment of international students, both on- and off-shore (Carrington et al., 2007; Harman, 2005; Mathews, 2002; McBurnie \& Ziguras, 2003; Sidhu, 2006; Marginson, 2011; Adams \& de Wit, 2011; Becker \& Kolster, 2012). On-shore recruitment applies to international students coming to Australia, and off-shore recruitment applies to international students accessing Australian higher education abroad through branch campuses, franchises, or twinning arrangements. In examining Australia's history of international education, it becomes apparent that these recruitment trends have not always been present.

Similarly to Canada, Australia began its contact with international students in 1950 as part of the Colombo plan (Smart \& Ang, 1996; Auletta, 2000; Cuthbert et al., 2008; Mathews, 2002; Sidhu 2006; Meek, 2011; Adams \& de Wit, 2011). The Colombo plan was part of a soft policy approach to diplomacy with the goal of establishing affiliations between Australia and the newly independent states. However, just as in the Canadian case, this approach changed dramatically in 1986 with the reshaping of government policy. Interestingly, these policy changes were not a direct result of changing foreign policy orientations-as was the case in Canada-but rather a result of a domestic educational policy shift. A series of changes in the funding of Australian higher education resulted in the introduction of neo-liberal practices that steered universities towards market like behaviours. In particular, the Jackson review of 1984 and the Dawkins reform of 1988 were identified as two policy instruments that eventually changed Australia's soft policy approach of "aid" to "trade" (Meek, 2011; Adams \& de Wit, 2011), enabling education to be perceived as an export industry. This commercialization of educational policy caused what Adams and de Wit (2011) describe as "anguish among academics, administrators, the community, and diplomats," with criticism coming to Australia from many quarters, especially Southeast Asia (p.34). 
Australian universities began charging full fees to international students and developing entrepreneurial initiatives to market Australian higher education abroad, leading to what Sidhu (2006) suggests was, "one of the most significant transformations in Australian higher education" (p. 184). The government's rationale for these sweeping changes was the urgent need to improve Australia's international competitiveness against the backdrop of a deteriorating trade deficit. Universities were thus encouraged to forestall this national economic crisis by accepting fees for the export of educational services. Thus, an international market-driven industry was implanted into a public funded educational system (Sidhu, 2006; Harman, 2005; Mathews, 2002; Gallagher, 2008; Marginson, 2011; Altbach \& Welch, 2011). To steer universities in this direction, the Australian government provided universities with grants of up to $\$ 200,000$ to develop promotional materials and marketing plans for the recruitment of international students. As a further incentive, institutions were allowed to retain a large proportion of the international student fee income. Universities began establishing international offices and developing infrastructure to market education and recruit international students (Adams \& de Wit, 2011). Earlier quotas on international students, which were established to ensure admission to Australian students, were removed, and universities were encouraged to charge a profit margin on foreign student tuition to generate revenue and make up any financial shortfalls (Sidhu, 2006; Smart \& Ang, 1996; Marginson, 2011). This encouraged an entrepreneurial spirit and attitude, and international student numbers in Australia grew exponentially as government policy moved away from subsidies, scholarships, or grants for foreign students (McBurnie \& Ziguras, 2003; Sidhu, 2006; Adams \& de Wit, 2011).

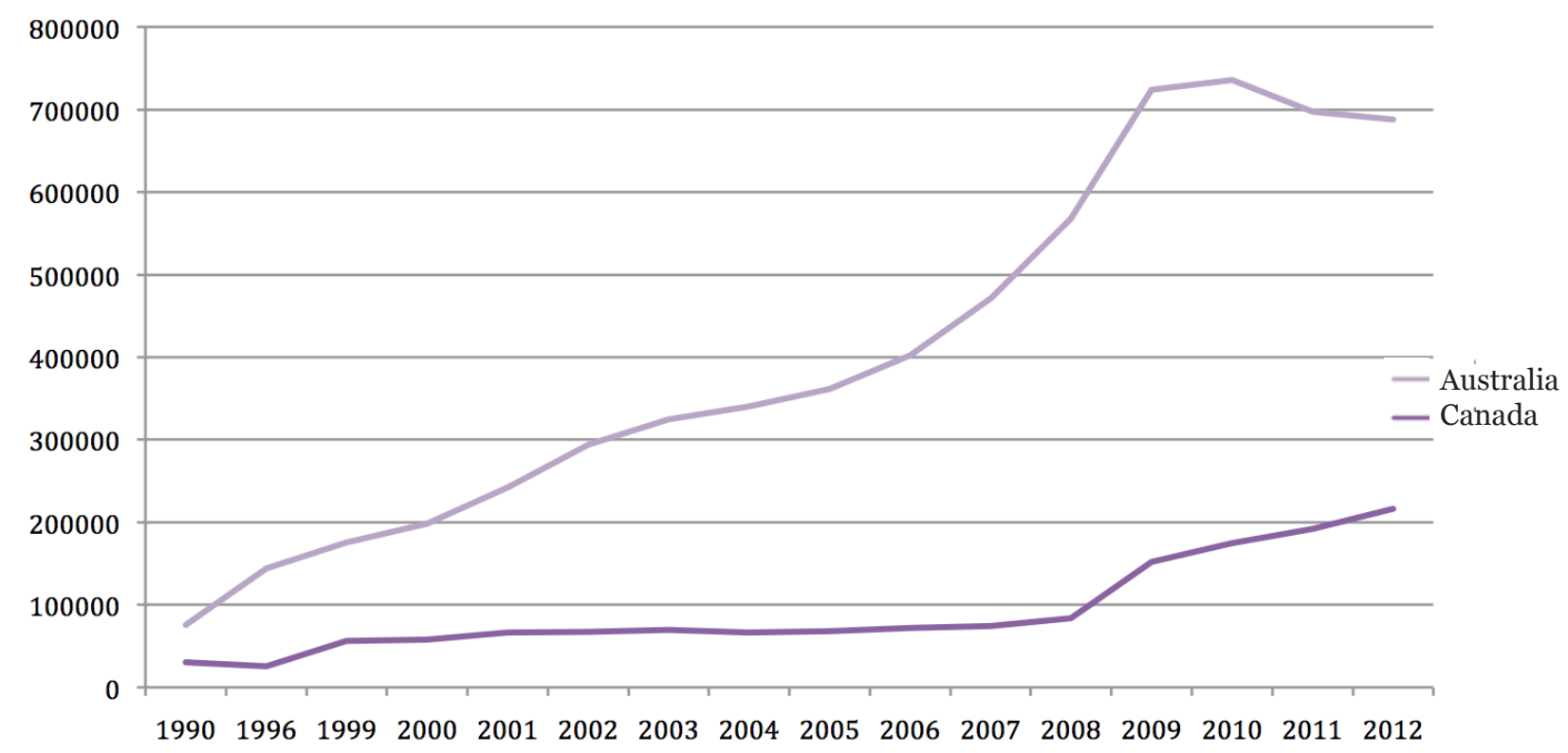

Figure 1: Relative growth of international student populations in Australia and Canada 
It is estimated that two thirds of international students in Australia are enrolled in on-shore programs, with the remaining third enrolled off-shore (Abubakar, et al., 2010). Although a higher number of international students are enrolled in university programs, private institutions-in particular vocational education and training institutions and English language schools-have experienced very high growth rates. It is no surprise therefore that Australia is ranked as the third largest exporter of higher education services behind the United States and the United Kingdom (Harman, 2005; Carrington, et al., 2007; Cuthbert, 2008; Marginson, 2011; Adams \& de Wit, 2011). In 2010, the total value generated by international students was estimated by the Australian Bureau of Statistics at $\$ 18.6$ billion -up from 2009 when it was estimated at $\$ 17.3$ billion, and reportedly resulting in over 100,000 full-time employment positions. This was followed by a decline in revenue the following year, in spite of optimistic future projects of student enrolments. (International Education Advisory Council, 2012). International education is touted as Australia's third largest export industry (Phillimore \& Koshy, 2010; Carrington, et al., 2007; Marginson, 2011; DIAC, 2011; Adams \& de Wit, 2011).

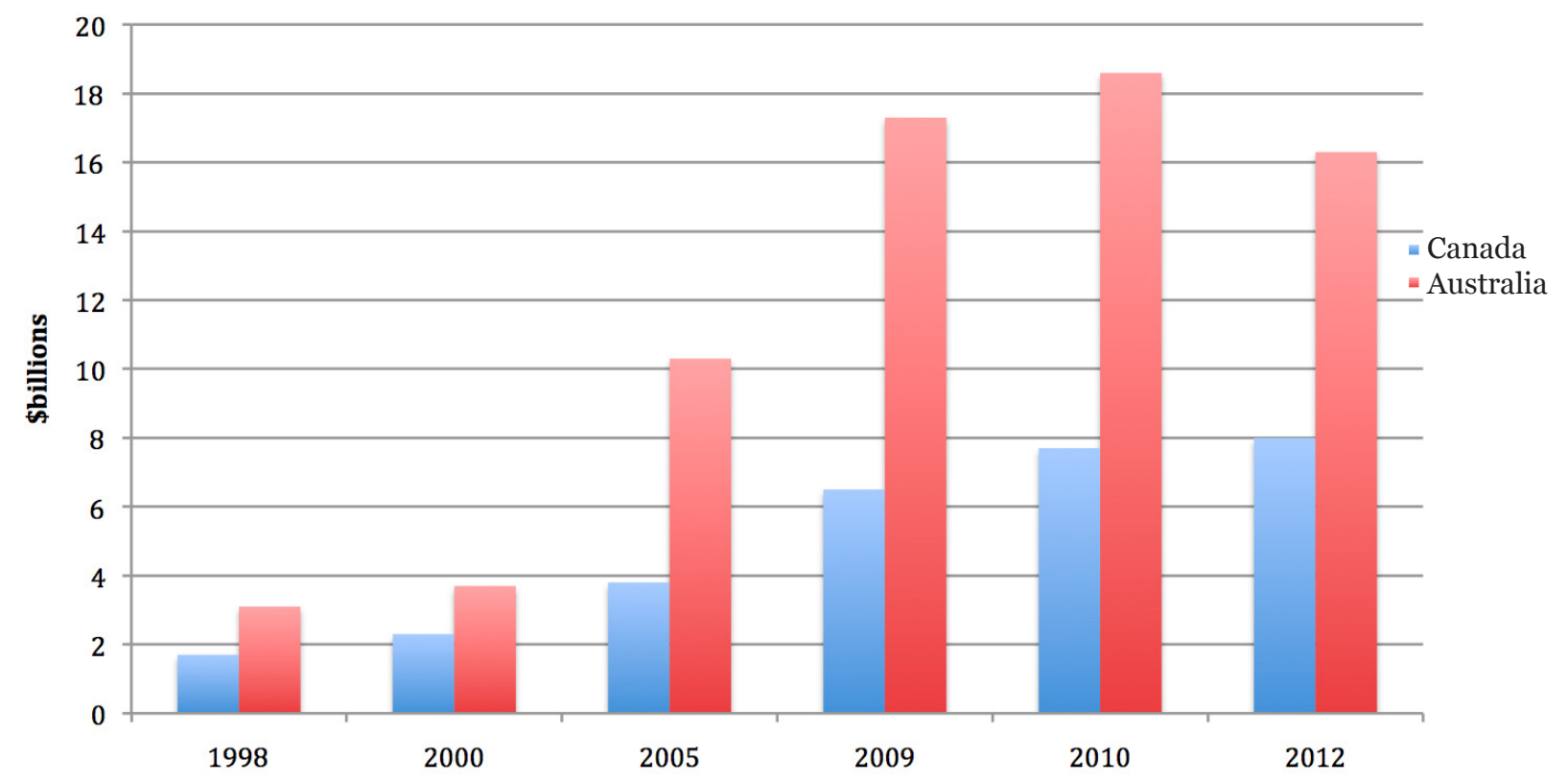

Figure 2: Revenue from international students

Gallagher (2002) speculated that by 2012, Australia would have three times the number of overseas students than in 2000-a rise from 200,000 to 600,000-and that by 2025, the number of international students could exceed one million and make up half of the entire student body! Although one could argue about the pros and cons of such growth and the optimal proportion of international to domestic students in a country, in the current Australian context, Gallagher's (2002) projections haven fallen short. As of 2009-2010, Australia has seen a drop of 9.5\% in new international student commencements (equivalent to more than 32,000 students). Although overall enrollments continue to rise, the sector is expecting a drop in numbers in the coming years. Declining enrollment is expected in the English language sector, private colleges, and the vocational education and training sector, substantially influencing future pathways and enrollments in universities (Kremmer, 2010; 
Meek, 2011; Marginson, 2011; Adams \& de Wit, 2011). Data on student visas also show a similar downward trend. Why do we see these changes in Australia's export industry? Is the Australian educational sector saturated, or is this decline indicative of increased competition for the recruitment of international students? Is there an overall decline in the global market of international students or is this trend specific to Australia? Is this cause for concern in the Australian government regarding its international education strategy?

\section{Australian International Education and International Students}

The singular focus on the recruitment of international students in Australia has resulted in several challenges.

Quality and reputation. Unfortunately, the pressure to succeed-success being defined as the increase in number of international student enrollments and associated revenue-has encouraged several institutions to engage in overzealous marketing efforts (Marginson, 2009, 2011; Adams \& de Wit, 2011). One of the first results of the trade-dominated focus on international education was, "the collapse of several English Language schools, concerns about a 'corporate cowboy' approach to recruitment, and accusations of immigration fraud" (Sidhu, 2006, p. 184). Fly by night educational operations sprung up in the vocational and English language training arena, leading to several cases of fraud (Marginson, 2011; Altbach \& Welch, 2011; Birrell \& Smith, 2010; Adams \& de Wit, 2011). Although a majority of fraudulent or unethical behavior occurred in the private sector (e.g., unscrupulous recruitment and graduation practices), even some colleges and universities lowered their standards of admission, engaged in collaborations with questionable marketing agents, and opened up new programs with insufficient resources and support services in order to attract international students for strictly revenue generation purposes. These approaches, albeit largely in the private, non-degree sector, encouraged several short-sighted and unethical advertising and recruitment efforts that arguably damaged the reputation of the Australian higher education sector (Cuthbert et al., 2008; Altbach \& Welch, 2011; Marginson, 2009; Adams \& de Wit, 2011; Altbach, 2012). They encouraged the admission of non-genuine students who were looking for back-door entry into Australia's workforce. In addition to distorting Australia's international education sector, these practices also negatively affected the integrity of its migration program (Knight, 2011).

Off-shore education in particular has raised several questions about Australian quality control. The domain of offshore education is extensive when considering the Australian case. In 2008, there were over 60,000 students enrolled in Australian universities in offshore locations, 42 percent in China and India (Adams \& de Wit, 2011). However, adequate systems have not yet been established to ensure equivalence of entry, teaching and assessment standards, financial viability of partner institutions, and the accuracy of marketing materials at host campuses (Edwards et al., 2010; Adams \& de Wit, 2011). There are also cases of insufficient allocation of staff and resources on home campuses to sufficiently communicate, monitor, and assess outcomes of these new ventures. Some institutions have entered into inappropriate arrangements with third party providers and failed to ensure effective quality assurance systems. Unfortunately, the Australian Universities Quality Agency (AUQA) audit reports indicate that Australian universities continue to make similar mistakes even though the costs to quality and reputation are substantial. Evidently, the pressure to generate revenue has resulted in Australia no longer 
being at the "premium end of the market" (Gallager, 2002). Articles such as, "Dark side to export boom," "Overseas student lured with false promises," and "Australia's universities must raise their standards before they raise students' fees" have become commonplace in Australian and international news (Sidhu, 2006).

In response to such practices, which the government sees as "back door" entries to immigration, student visa rules were tightened and the list of preferred occupations for immigration purposes was shortened (Kremmer, 2010; DIAC, 2011). This resulted in conflicts between different stakeholder groups and, as Altbach (2011) comments, "politics, money and education [in Australia] became intertwined" (p. 2). Government regulations on immigration can serve to encourage or restrict educational exports. Australia moved towards relatively high restrictions on the entry of foreign students, resulting in Australia's reputation as an increasingly unfriendly country to international students (Carrington et al., 2007; Marginson, 2011).

Mindful of the importance of international education and the need to maintain Australia's competitiveness, the government appointed the Hon. Michael Knight AO (Order of Australia) to conduct its first independent review of the student visa program in 2010. The government supported all of Knight's 41 recommendations, "to enhance the quality, integrity and competitiveness of Australia's education sector and improve the integrity of the student visa program" (DIAC, 2011, p. 2). Following Knight's recommendations, a number of changes have been proposed that will streamline visa processing and reduce waiting times for prospective students. For example, high-quality, low-risk educational providers such as reputed universities will be given faster and easier visa access for their prospective students. Similarly, financial requirements for higher risk providers such as non-university and vocational institutions will be substantially lowered, and arrangements will be made to enable English language training in Australia. In keeping with its competitor countries, Australia is also revising its work-related legislation to further enable degree-level students to access post-study work visas. To facilitate coordination and communication between the different stakeholder groups, the government has also proposed an ongoing Education Visa Consultative Committee (DIAC, 2011). Because these policy changes are being announced concurrently with the publication of this paper, the effects of this reversal concerning international students and immigration have yet to be seen.

In response to these growing concerns of maintaining the quality and reputation of Australian universities, the Australian government also introduced the Education Services for Overseas Students (ESOS) Act in 1991 and subsequently updated it in 2000. "ESOS, the Beazley Ministerial Statement and the AVCC's [The Australian Vice-Chancellors' Committee] code of ethics practice for the provision of education to international students were all part of a broader discursive ensemble aimed at curbing the fallout from the free market era of international education" (Sidhu, 2006, p. 186; Nyland et al., 2010). While these guidelines are useful, they are not a set of policy or prescriptive norms. Instead, they leave each institution a choice to self-regulate. Other initiatives that have been introduced include further amendments to ESOS Act requiring international education providers to re-register, and the release of the Council of Australian Government's International Students Strategy for Australia (DIAC, 2011). All of these initiatives are efforts to rebuild trust and, "safeguard a sustainable future for good quality international education in Australia" (Becker \& Kolster, 2012, p. 40). Recognizing the consequences of an entirely commercial policy 
focus in Australian institutions and the related criticism and pressure from client groups, the Australian government has also begun to signal a broader vision for international education, including cooperative linkages and networks, internationalization of curriculums, student mobility, and scholarships to attract postgraduate international research students (Beazley, 1992; Harman, 2005; Adams \& de Wit, 2011; Becker \& Kolster, 2012).

High dependence on few sender countries, programs, and levels of education. The dependence on source countries is influenced by several economic factors such as the level and distribution of income in foreign countries, real exchange rate movements, changes in government regulations, course and living costs, changes in course curricula, etc. (Carrington, et al., 2007; Meek, 2011). This volatility makes institutions with a high international student population vulnerable, especially those with a strong dependency on a few countries. Asians comprise a majority of international students in Australia, making up over $80 \%$ of the international student body. China and India are the two biggest source countries and account for over $43 \%$ of the international student body (Adams \& de Wit, 2011). Other top sender countries include Malaysia, Korea, Indonesia, Vietnam, and Thailand (Mathews, 2002; Harman, 2005; DFAIT, 2009; Meek, 2011; Becker \& Kolster, 2012). Overall, international students represent approximately $20 \%$ of total students in Australian universities, although this percentage fluctuates from $3 \%$ all the way to $44 \%$ across individual universities (Gallager, 2002; Harman, 2005; Marginson, 2011).
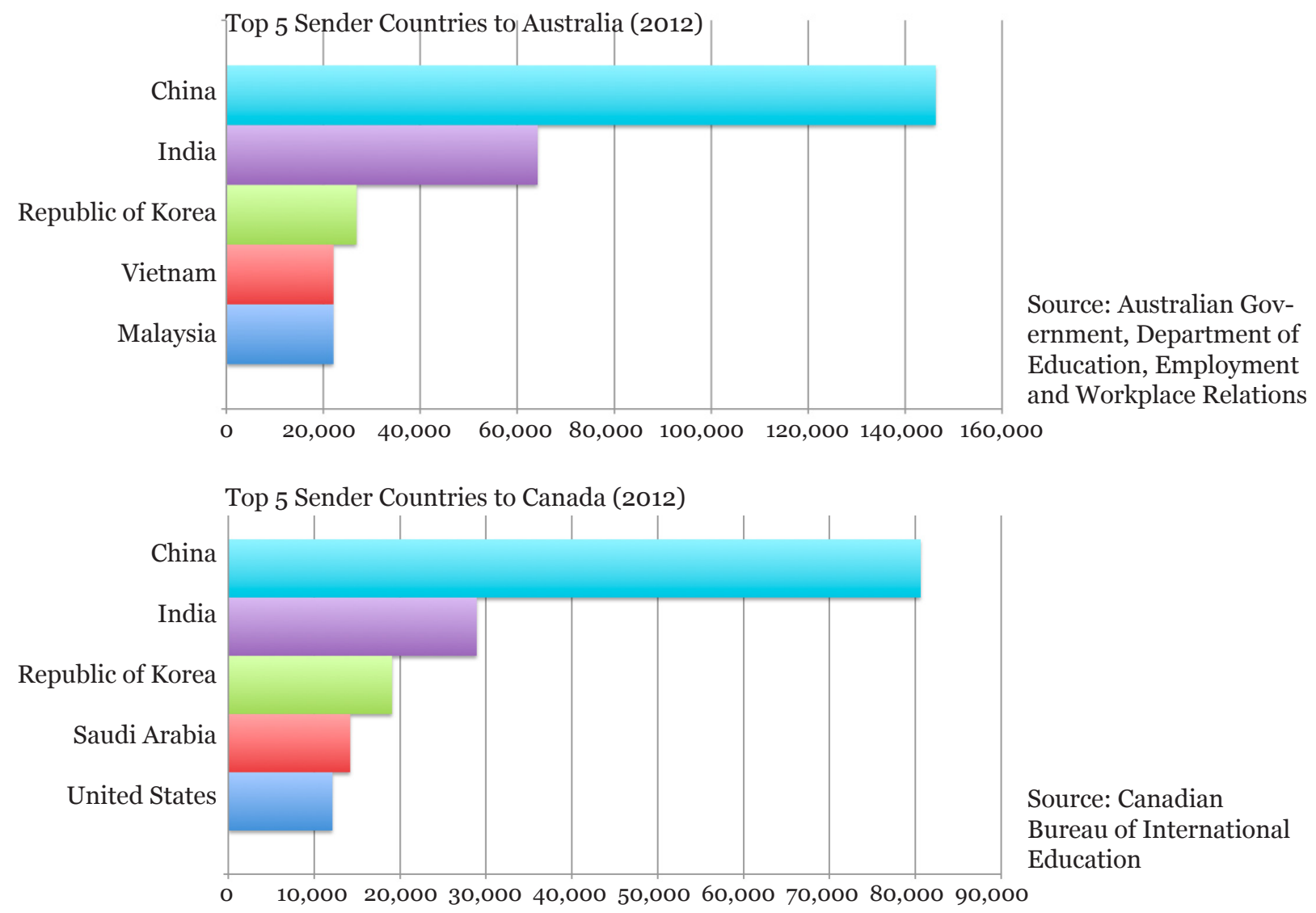

Figure 3. Five top sender countries for Australia and Canada (2012) 
Australian universities experience very high concentrations of international students in a few subject areas. More than 50\% of international students-and $67 \%$ of the Chinese cohort-study business or commerce (Sidhu, 2006; Victorian Auditor-General, 2009; Becker \& Kolster, 2012). Such a concentration results in pressures associated with adequate support and relevant teaching practices, restricted international experience for both Australian and international students, and an imbalance in the concentration of demand for more market driven subjects. There are also increasing complaints from domestic students and faculty related to quality and standards, with some faculty accusing the institution of lowering academic standards and encouraging "soft" marking.

Competition for the enrollment of foreign students is another reason for vulnerability and fluctuations in the international student market. In addition, changes are also occurring in what were traditionally "sending" countries such as Hong Kong and Singapore. They are moving to become international educational destinations themselves (Harman, 2005; Becker \& Kolster, 2012). Large markets such as China and India are also moving to build their own domestic education systems and are thus encouraging more of their citizens to study at home. There are also new 'knowledge hubs' such as Dubai's knowledge village or Qatar's education city that are attracting an increasing number of international students. Identifying and developing markets for international education export is a sophisticated and complicated venture that requires substantial data, research, resources, and a global strategic orientation. The significant and growing revenue from international students is not guaranteed. In fact, international student enrollments are influenced by several push and pull factors between different countries and are vulnerable to fluctuations in the political, economic, or socio-cultural circumstances of countries. Most often these fluctuations are unpredictable, making universities with a high dependence on specific countries or programs vulnerable (Gallagher, 2002; Meek, 2011; Kolster \& Becker, 2012).

Australia has a much higher percentage of undergraduate students than graduate or post-doctoral students and researchers (approximately 70\%). Its proportion of international students in advanced research programs (17.8\%) lags behind competitive universities by up to 50 per cent-PhD students are widely considered a talent metric vital for economic development and innovation (Hazelkorn, 2008). In light of the anticipated benefits of hosting international students to Australia's knowledge, economy, and society, such a trend of increasing undergraduate students is inadequate. To attract graduate scholars and researchers, the Australian government allocated Au\$7.9 million to create the Endeavour Awards. While this program is progressive, the bulk of Australia's focus on international student recruitment remains at the undergraduate, vocational, or language training level. Once again, the desire to draw revenue from international education has taken precedence over attracting research talent with the potential to truly bolster the Australian economy.

Acceptance of diversity and "the other." Although the recruitment rhetoric suggests greater internationalization of university campuses, studies conducted on Australian and international students suggest that the two groups mix relatively uneasily and infrequently on Australian campuses (Harman, 2005; Mathews, 2002; Marginson et al., 2010). There is an assumption that cultural osmosis will happen naturally; however, as seen through the Australian experience, the mere presence of international students cannot be equated with intercultural diversity. In contrast with the multicultural imagery 
used to market international education, most international students find university programs and environments that are primarily monolingual, largely westernized, and Eurocentric. The level of satisfaction international students experience in meeting domestic students and integrating with university culture is considerably lower than other aspects of their university experience (Harman, 2005). As Harman (2005) rightly suggests, this raises the broader question, “...to what extent does the presence of international students on Australian campuses contribute to the internationalization of Australian education and training?" (p. 133). Given the high percentages of international students on Australian campuses, several international students have raised additional questions on the appropriateness of teaching methods, curriculum, and supervisory practices for international-especially Asian-students (Adams \& de Wit, 2011).

Despite growing student safety issues on campuses, both the Australian government and educational institutions have reassured sender countries that Australia is a safe country (Nyland, et al., 2010). In 2007, the Australian government made minor amendments to the ESOS act in terms of services to international students. In spite of the Australian Education International staff reporting that $75 \%$ of international students were not satisfied with safety provisions in Australia and similarly condemning reports from academics, journalists, and police officials, the Australian government continuously denied any student safety issues until 2009. Chinese and Indian students were victims of a high number of robberies and assaults as well as exploitation in the housing and employment market. Subsequently, the Chinese and Indian governments intervened and demanded that Australia take immediate steps to rectify the safety situation. They forced Australia to acknowledge that there is a systemic international student safety problem and to embrace policies and practices to address this problem. Birrell and Smith (2010) suggest that these issues are a result of the Vocational Education and Training (VET) sector attracting a higher number of Indian students from regional, rural, and poor backgrounds since 2008. With low English proficiency, these students-who are often not genuine students-are more likely to seek low-wage, illegal employment. Regardless, these incidences created negative publicity and affected international student enrollment. In 2008 and 2009, for example, several Indian students were attacked, and the publicity of these events resulted in a 19\% drop in their enrollments at Australian universities (Marginson, 2011; Becker \& Kolster, 2012).

As a result of these incidents, several state governments have now created investigative bodies to examine cases concerning international students. The Commonwealth government also paid for additional resources such as safety guides to rebuild its reputation as a safe place. The government fast-tracked a review of the ESOS act to tighten its regulatory provisions. It even sent a high-level delegation to India to assure the Indian press and community that the issue of student safety was being taken seriously (Nyland et al., 2010). Universities Australia (formerly the Australian Vice-Chancellors' Committee, AVCC) published an action plan for student safety clearly abandoning its previous claim that international student safety is not a systemic problem in Australia. Through these difficult and unpleasant experiences, the Australian government and Australian educational institutions have been forced to realize that student support services and safety cannot be sacrificed in the interest of economic profitability.

Other factors. As mentioned above, visa and immigration regulations can serve both as a push or pull factor for international student recruitment. Australian universities were 
confident that the education-immigration link and the ease with which it was sustained would continue the steady stream of the international students arriving in Australia. But in 2008, the skilled immigration program was cut significantly, and this change in immigration regulations proved a threat to the recruitment and retention of international students (Marginson, 2011; Meek, 2011). The tightening of visa regulations further resulted in a high denial rate of students from important sender countries like India. The Australian government was urged to ease immigration rules, particularly those requiring students to prove necessary funds for their entire educational costs-a practice not followed by any of their competitor countries (Kremmer, 2010; DIAC, 2011). The Australian government was also advised to stop viewing student-visa holders as part of the government's efforts to lower overseas immigration levels (Kremmer, 2010; Marginson, 2011). The subsequent changes made to visa processing to maintain Australia's competitive advantage have already been outlined above.

The ongoing international financial downturn and the rising value of the Australian dollar have also affected Australia's command of the international education market. During the 1990s, the Australia dollar averaged US\$0.71, reaching a peak of US\$0.81 and a low of US\$0.55. By April 2001, the Australian dollar had sunk even lower, reaching an all-time low of US\$0.50. Like other export industries, education becomes more attractive when the local currency falls, particularly to such a low rate. International students get more value for their money, and this plays a role in their decision making process. Following its low point in the spring of 2001, the Australian dollar slowly began to rise. This rise became even steeper as the years went on, until the jumps became more drastic: In January 2007, the Australian dollar rested at US\$0.78, and exactly one year later it had gone up to US\$0.88. In February 2011, it surpassed the US\$1.00 mark and has hovered thereabout ever since. This significant rise in the local currency has negatively affected myriad export industries in Australia and education is no different. The high cost of international student tuition can act as even more of a deterrent when the local currency rises considerably, especially when competition is growing from both developed and emerging countries with more competitive tuition rates. Thus, the changes in immigration policy, the global economic recession, and rising value of the Australian dollar have combined to make Australia seem less attractive as a destination for international education than it was in the past (Marginson, 2011). Canada has witnessed a similar rise in its currency relative to the US dollar, and, although its tuition rates seem competitive, it would be prudent for it to make note of fluctuating currency rates, global financial downturns, and the increased competition from existing and emerging recruiter countries in developing and implementing its international education strategy.

\section{Revisiting Internationalization? The Australian Case}

In 1992, partly because of the widespread domestic and international criticism of its excessively commercial orientation, the Australian federal government signaled a major policy shift from trade to the genuine internationalization of education (Smart \& Ang, 1996; McBurnie \& Ziguras, 2003; Cuthbert et al., 2008; Harman, 2005; Adams \& de Wit, 2011). International education is increasingly being framed in the context of Australia's international and cultural relations and its enrichment of Australian education and society. Adams and de Wit (2011) label it as the third phase of Australia's international educa- 
tion, one that is more balanced and sustainable in its approach. The major thrust of the new policy is to foster stronger academic and research ties with universities in Asia and place a greater emphasis on reciprocity, including staff and student exchange. Although the federal government has committed modest sums to promote the University Mobility Abroad Program and the Targeted Institutional Links Programs-which fosters research links-and invested in scholarships to attract advanced research students (Becker \& Kolster, 2012), the thrust of the international education policy approach still remains market driven and trade centered (Smart \& Ang, 1996; Adams \& de Wit, 2011). Australia's national education policy, "Engaging the world through education," commits Au $\$ 113$ million to international education, however a lion's share, consisting of Au $\$ 41.7$ million, still goes towards promotion and marketing activities.

Although several challenges and drawbacks of the Australian approach to international education have been highlighted, we would be remiss if we did not address the strengths of the Australian model. A significant body of research on several aspects of the international student experience has come out of this emphasis on international education. A high number of research studies have been conducted in Australia on various aspects of international student selection, transition, performance, and post-graduation plans that could provide substantial input into policy, practice, and pedagogy (Cuthbert, et al., 2008; Meek, 2011). Similarly, the various challenges faced within the Australian context have resulted in several coherent and systematic principles, policy statements, and guidelines for best practices. For example, Australia has outlined principles of engagement, codes of conduct, due diligence procedures, partnering standards for customer service, management of customer relations, an approval process for international activities, and many other government and university regulatory frameworks (Gallagher, 2002; Becker \& Kolster, 2012). Finally, Australia's international education policy and the government's commitment to the international education industry resulted in building Australia's image as a front runner in international education, providing added competition to traditional host countries, establishing itself as a major bridge builder within the Asian continent, and being recognized as leader in the marketing of international education. Carrington et al. (2007) suggest that different forms of government intervention within specific national contexts induce different behavioural responses from educational providers in developing export markets. Let us have a look at some of the specifics of the Australian case.

Coordinated and centralized policy structure. Like Canada, Australia has a Department of Foreign Affairs and Trade (DFAT). However, unlike in Canada, DFAT's agenda is intricately linked with the mandate and policy direction of the Department of Education, Science and Training (DEST), renamed the Department of Education, Employment and Workplace Relations (DEEWR) as of 2008. Although DFAT does not provide any direct funding to international education activity, it nonetheless provides both policy and diplomatic support to its operations (AEI \& DOE, 2002). It is important to note that in Australia, the Minister for Foreign Affairs provided support through the Economic Analysis Unit and jointly launched the government's first international education policy statement along with the Minister of Education.

There is a commitment within Australia to develop a government-wide approach to education promotion overseas. In the past, the main international education activity was 
carried out by Australian Education International (AEI), a division of DEEWR created as part of its international portfolio. Within the Department of Education there is an International Policy Branch (IPB) and the National Office of Overseas Skills Recognition (NOOSR). Outside the department of education, the Australian Trade Commission (Austrade) also promotes Australia's education experience. Outside the government, but with the engagement of Australian universities as shareholders, IDP, a for-profit company, helps to promote the export of the Australian education industry. IDP identifies itself as the world's largest international student placement provider and indeed has a huge global reach, including a network of over 80 international student placement centres located in more than 25 countries. Instrumental to the growth of the international student program in Australia, IDP focuses on three major business arms: recruitment of international students, English language testing, and management of international aid projects (Adams and de Wit, 2011). IDP's scope of coordination impressively includes collaborations with national recruiting bodies such as the British Council and an established presence in the North American market. The Australian Universities International Directors' Forum (AUIDF), a non-governmental grouping of international directors, has also played an important role in setting benchmarks for international activity from which universities can judge aspects of their performance against industry norms (Adams and de Wit, 2011).

In 2009, in response to growing criticism and the questionable reputation of the international education export sector, the Australian government transferred the responsibility for the international promotion and marketing of Australian education from Australian Education International (AEI) to Austrade. AEI now leads strategic policy, regulation, and government-to-government engagement in the international education sector (Oliver, 2010). In light of the nature of these criticisms, it is intriguing that Austrade, Australia's Trade Commission, now has responsibility for the international marketing and promotion of Australian education and training. One wonders if this shift further strengthens opinions that Australia is in the "business" only for the economic gain? (Oliver, 2010).

Commitment reflected in nature and levels of funding. The federal government provides fairly substantial funding and policy support for international education promotion through both DEEWR and AEI. The budget for international education is approximately $\mathrm{Au} \$ 113$ million (at a net cost of $\mathrm{Au} \$ 10$ million to the Commonwealth). The initiatives included Au\$41 million in additional funding over the next four years to increase the promotion of Australian education overseas (Carrington et al., 2007). Direct and substantial funding to Australian educational institutions enables the federal government to steer the direction of higher education policy, and, most importantly, make policy and program decisions unilaterally (i.e. with little if any input from the states or other government departments).

Policy coordination and approach. As demonstrated above, Australia's policy and program approach is more direct and hands-on than Canada's-direct because it is linked to DEEWR's policy objectives and DFAT's foreign policy agenda, and hands-on because the program approaches are focused in terms of geography and outcomes. It is important to note that the Australian Government was among the first to freely use terms such as educational industry, commercialization of higher education, key markets for trade in educational services, global educational market, and emergence of borderless market for international education, and directly link education with the promotion of 
international trade agreements (Nelson, 2003). In the current visa processing exercise, the policy coordination efforts are taking place between the Ministry for Immigration and Citizenship and the Ministry for Tertiary Education, Skills, Jobs and Workplace Relations, a division of DEEWR.

\section{Comparing Canada with Australia}

In 2008, DFAIT identified the following four reasons for Canada's substandard performance in the international education market: Canada did not have an international brand for its education system, a coordinated marketing strategy, or adequate support for promotion, and its missions abroad lacked policy and direction. Academic Michael Goldberg of the University of British Columbia captures this pervasive dissatisfaction: "Canada is the only country in the world lacking a national education ministry and the institutional ability to market its educational services in an integrated way" (Cernetig, 2009, p. 1). In the criticism of the Federal Government's lack of a national branding strategy, Canada has been regularly stacked up against other Western nations-Australia in particular-that have long had a national brand and a policy for international education.

The Australian situation is significantly different in its coordination of national educational policy. In Australia, both foreign affairs and higher education are the responsibility of the Commonwealth. In addition, DEEWR and DFAT have harmonized their agendas and the Federal Government has taken a leading role in creating a national policy for international education in the absence of any cooperative or collegial policy coordinating mechanisms. This has resulted in a centralized, top-down policy approach that limits the involvement of state and other organizations and has made international education-specifically international student recruitment-a critical driver of educational policy (Harman, 2005).

Although Australia epitomizes hard federalism, and Canada conversely represents a highly decentralized and uncoordinated form of federalism, both government structures have a strong influence on international education policy development. In fact, because of frequent resistance from CMEC and the provinces and a lack of coordination between different stakeholder groups, we would argue that the Canadian federal structure has eventually acted as a buffer and prevented us from moving too quickly in Australia's direction of transforming education into a pure trade commodity. Marginson (2002) rightly suggests that the Australian experience provides something of a guide-and a salutary warning-to other jurisdictions.

The outcomes from the marketing-oriented approach pursued by Australian universities have already been highlighted. Canada has always welcomed international students and, in recent years, seen them as potential immigrants. We do not suggest that Canada stop recruiting international students or abandon developing a national policy or brand; we do however recommend that international student recruitment should be pursued in sync with the broader academic, social, and cultural aims of Canadian post-secondary institutions. Australia has finally learnt-albeit a bit late-that when education is viewed as soft power in international diplomacy rather than trade it results in a broader and more respected agenda.

Unfortunately, current trends within international education have normalized the discourse of education as a tradable commodity (Sidhu, 2006). These trends have led both the government and educational sectors to believe that the current economic approaches 
are inevitable. To compete in the international market, it is necessary for a country or individual institution to become part of the pecking order of international ranking systems. Are these forces necessarily irresistible? Has Canada not managed to produce internationally ranked universities without having recourse to national policies that are highly commercial, market driven, and aggressive in their recruitment of international talent? International education policies such as those adopted by the Australian Government eventually impact domestic educational policies, increasingly moving universities away from being public institutions. The same revenue-generation and full-cost recovery models rationalized for the international market also penetrate domestic policies. The Australian Government had to create new legislation and audit measures in response to the challenges resulting from their highly commercial approach to international education. These new measures added additional costs and, perhaps more importantly, increased the surveillance role of the government over educational institutions and universities. What are the implications of such measures to values of institutional autonomy?

\section{Conclusion and Recommendations}

We conclude with a set of recommendations for the Advisory Panel, DFAIT, and other departments and stakeholder groups that have a mandate to develop an international education strategy and brand and market Canadian higher education.

Education, both international and national, has to be considered a long-term investment and not a commodity. It should be linked closely with broader national and foreign policy goals and recognize higher educational institutions as local, national, and global assets. Attracting global markets and increasing degree attainment rates of the domestic population are not mutually exclusive goals and can be considered hallmarks of a competitive economy. Internationalization and international education cannot be marginalized as a policy consideration-they have to instead become central to our provincial and national policies on education.

Similarly, we should discourage pitting international students against domestic students for admissions and aid. Capacity for both groups of students should be expanded. Issues of access, funding, and completion are equally important to both groups. Measures should be taken to address any possible differences in the treatment and support of domestic and international students, and the issue of a lack of communication between two the student groups should be addressed.

Marketing requires research, strategic planning, and implementation. We need to think creatively about our enrollment capacity and develop diversified approaches for different market sectors. It is essential that we diversify students by recruiting from a wider range of source countries and fields of study. Similarly, we must maintain a good balance of undergraduate and graduate students, including research students.

The Australian experience demonstrated that high-risk offshore educational opportunities offer lower yields. We should be especially careful in developing these ventures and keep in mind the need for adequate staff and resources to communicate and monitor these agreements. Although Canadian universities have been slow to set up offshore locations, the Association of Universities and Colleges of Canada's (AUCC) 2006-07 survey on internationalization at Canadian universities indicates that it is a growing trend in $\mathrm{Ca}$ nadian higher education. In fact, AUCC notes that offshore delivery of education provides 
the foundation for other types of value-added activities, such as internships, research collaboration, and professional development. The emphasis on promoting Canadian offshore campuses and other international education marketing initiatives are evident in the Consultation Form circulated by DFAIT to seek input into the development of Canada's international education strategy (DFAIT, 2011). Reassuringly, AUCC has emphasized caution against knowledge exports solely motivated by revenue generation and suggested quality assurance guidelines for offshore delivery, acknowledging the significant human resource involvement, solid legal agreements, and infrastructure required.

We have tasted some success in coordinating policy, and we should continue in this direction, working towards an integrated government policy framework and approach while recognizing the interests and jurisdictions of a multitude of stakeholder groups. In particular, it is essential that we keep in mind the educational jurisdiction of the provinces and their growing commitment to international education, and, where possible, encourage and support initiatives both at the federal and provincial level.

Future growth is expected in the international student market. There will be both traditional and new competitor countries vying for additional international students. In the context of recruitment, it is important to recognize that countries such as the United States, which enrolls the largest number of international students worldwide, began investing in international education in the 1930s. Furthermore, international student recruitment is just one of the many exchange and international education programs the U.S. government supports. This approach enhances their profile and connections within educational communities. Further, situating these programs within the network of official government overseas offices and federal funding programs establishes their legitimacy. Hence, it is important to invest in government or national organizations that have a broader mandate towards educational and cultural diplomacy, with international education recruitment being one of the several programs implemented to enhance the overall quality and reputation of research and scholarship in higher education. Developing international scholarship and fellowship programs, new and innovative international partnerships and collaborations, and reinforcing reciprocity by way of a two-way flow of students, staff, and investments will have an indirect effect on the reputation and quality assessment of a country's educational system, leading to increased international student flows.

Finally, it is prudent that we take heed of Knight's cautions regarding the five myths of internationalization, especially noting that the presence of more international students will not necessarily help internationalize a particular campus, nor will it necessarily improve the quality of an institutions international reputation. Additionally, it is worth noting that the goals of internationalization are not synonymous with those of international marketing campaigns designed to improve an institution's global brand or ranking (Knight, 2011).

\section{Note}

1. Subsequent to the submission of this paper, the expert advisory panel made its recommendations and submitted its report to the government on August 14, 2012. This report titled, International Education: A Key Driver of Canada's Future Prosperity is a comprehensive and expansive report, offering a total of 14 recommendations under five core themes: targets for success; policy coordination and ensuring sustainable quality; 
promotion of education in Canada; investments, infrastructure, and support. While the report does offer a number of excellent recommendations for the development of Canada's international education strategy, in lieu of its recommendation that Canada double its intake of full-time international students by 2022 and its focus on the marketing of Canadian education and the recruitment of international students, we propose that a comparison with the Australian case is particularly relevant and meaningful

\section{References}

Abubakar, B., Shanka, T., \& Muuka, G.N. (2010, July). Tertiary Education: An Investigation of Location Selection Criteria and Preferences by International StudentsThe Case of two Australian Universities. Journal of Marketing for Higher Education, 2O(1), 49-68.

Adams, T., \& de Wit, H. (2011). Global Competition in Higher Education: AComparative Study of Policies, Rationales and Practices in Australia and Europe. In H. de Wit (Ed.), Trends, Issues and Challenges in Internationalisation of Higher Education (pp. 2938). Amsterdam: Centre for Applied Research on Economics \& Management, School of Economics and Management.

Altbach, P. (2012, April 5). Down the Slippery Slope-The New Commercialism and the Decline of Standards. Retrieved from http://www.insidehighered.com/blogs/ world-view/philip-g-altbach-down-slippery-slope--new-commercialism-and-declinestandards

Altbach, P., \& Welch, A. (2011). The Perils of Commercialism: Australia's Example. International Higher Education, 62(Winter), 21-23.

Asia Pacific Foundation of Canada. (n.d). Retrieved from http://www.asiapacific.ca/ data/devt/donor_dataset4_compare.cfm

Association of Universities and Colleges of Canada. (2002). International Student Recruitment. Ottawa: AUCC.

Association of Universities and Colleges of Canada. (2007), Internationalizing Canadian Campuses. Ottawa: AUCC.

Association of Universities and Colleges of Canada. (2012). Directory of Canadian Universities. Ottawa: AUCC.

Auletta, A. (2000). A Retrospective View of the Colombo Plan: government policy, departmental administration and overseas students. Journal of Higher Education Policy and Management, 22(1), 47-58.

Australian Department of Foreign Affairs and Trade. (2005, May 6). Trade in Services Australia, 2003-4. Retrieved from http://www.dfat.gov.au/media/releases/department/ doo5_04.htm.

Australian Education International and Department of Education. (2003, October 14). Summary Extracts of Engaging the World through Education: A Ministerial Statement on the Internationalisation of Australian Education and Training. Retrieved from http:// www.foreignminister.gov.au/releases/2003/joint_education.html 
Australian Education International. (n.d). Structural change and growth in the international education industry 2002-2012. Retrieved from http://www.idp. com/16aiecpapers/program/thursday/marketing2/Gallagher_pp.pdf>

Australian Education International and Department of Education. (2003). Australian International Education and Training at a Glance: A supplement to Engaging the World Through Education. Retrieved from http://aei.dest.gov.au/AEI/AboutAEI/ PoliciesAndPriorities/MinisterialStatement/PPAtAGlance_pdf.pdf

Australian Education International and Department of Education. (2003, October). Engaging the World Through Education. Retrieved from http://aei.dest.gov.au/AEI/ AboutAEI/PoliciesAndPriorities/MinisterialStatement/Minstatement_pdf.pdf

Australian Education International and Department of Education. (2002, April). Review of Australian Education International, Research, Analysis and Evaluation Group. Retrieved from http://www.dest.gov.au/NR/rdonlyres/46D3D4BB-7C4F-4AEA-9EA6DE55BBD905BC/1199/AEI_review_2002.pdf

Australian Education Network. (2012). University and College Guide. Retrieved from http://www.australian-universities.com/

Australian Government Minister for Trade. (2003, October). Education to Focus on Exports in Mackay. Retrieved from http://www.trademinister.gov.au/parlsec/ mediareleases/031022.html.

Australian Minister of Foreign Affairs. (2005, September 7). Education without Borders: International Trade in Education. Joint Press Conference with Alexander Downer and Brendan Nelson and Repost launch of Minister of Foreign Affairs. Retrieved from https:// www.foreignminister.gov.au/transcripts/2005/050907_joint_press_conferenne.html

Australian Ministers for Trade. (2005, September 7). Joint Press Conference with Alexander Downer and Brendan Nelson: Report Launch of Education without Borders International Trade in Education.” Retrieved from http://www.trademinister.gov.au/ transcripts/2005/050907_joint_pr_html

Beazley, Hon. K. (1992). International Education in Australia through the 1990 . Canberra: Australian Government Publishing Service.

Becker, R. \& Kolster, R. (2012). International Student Recruitment: Policies and Developments in Selected Countries. Netherlands: NUFFIC.

Birchard, K. (2007, November 29). Canada Starts a 'Branding' Campaign to Help Universities Recruit More Foreign Students. The Chronicle of Higher Education. Retrieved from http://chronicle.com/daily/2007/11/828n.htm

Birrell, B., \& Smith, T.F. (2010). Export earnings from the overseas student industry: how much? Australian Universities Review, 52(1), 4-12.

Bond, S., \& Lemasson, J. (Eds.). (1999). A New World of Knowledge. Canadian Universities and Globalization. Ottawa: IDRC.

Breithaupt, H. \& Caddick, S. (2008). Australian Universities: neither down nor under. An interview with Micheal Gallagher, Executive Director of the Group of Eight coalition of Australian universities (EMBO reports, 600-604). Retrieved from http://www.nature. com/embor/journal/v9/n7/full/embor2008108.html 
British Columbia Council for International Education. (2009, October). Education au/in Canada Brand Training Workshop. BCCIE eNews. Retrieved from http://www. bccie.bc.ca/docs/enews_archive/October2009Issue1_archive.pdf

Canadian Bureau for International Education. (2010, June 29). Five national education associations establish the Canadian Consortium for International Education Marketing. Retrieved from http://cbie.ca/data/media/releases/20100629_e.pdf

Carrington, R.,Meek,V.L.,\&WoodF.(2007).Theroleoffurthergovernmentintervention in Australian international education. Higher Education, 53, 561-577.

Cernetig, M. (2009, June 17). What Canada has is a branding gap. Vancouver Sun. Retrieved from http://www.vancouversun.com/index.html

Coaldrake, P. (1999). The Changing Climate of Australian Higher Education: an International Perspective. Higher Education Management, 11(1), 117-135.

Council of Ministers of Education. (1998, October). "Memo from Sergio Marchi, Chairof Board, Minister of International Trade, regarding set-up of Advisory Board." FPPECERIA.

Council of Ministers of Education Canada. (1991), Federal-Provincial Consultative Committee on Education-Related International Activities. FPCCERIA.

Cudmore, G. (2005). Globalization, Internationalization, and the Recruitment of International Students in Higher Education, and in the Ontario Colleges of Applied Arts and Technology. Canadian Journal of Higher Education, 35, 1.

Cuthbert, D., Smith, W., \& Boey, J. (2008). What Do We Really Know About the Outcomes of Australian International Education? A Critical Review and Prospectus for Future Research. Journal of Studies in International Education, 12 (3), 255-275.

Davidson, D., Knight, J., McBride, K., Best, G., \& MacKechnie, C. (2009, November 11). It's time to maximize benefits from international students. The Embassy. Retrieved from http://www.cbie.ca/english/media_news_htm

Department of Foreign Affairs and International Trade, Canada. (1991, February 22). International Cultural Relations. Academic Relations, Vol. 13, File 55-11.

Department of Foreign Affairs and International Trade, Canada. (1994). The International Dimensions of Higher Education in Canada Collaborative Policy Framework, Draft Discussion Paper.

Department of Foreign Affairs and International Trade, Canada. (2008). Canada's Competitive Challenge: International Promotion of Education - New Initiatives. Ottawa: DFAIT.

Department of Foreign Affairs and International Trade, Canada. (2009, July). Economic Impact of International Education in Canada. Vancouver: DFAIT. Retrieved from http://www.international.gc.ca/education/assets/pdfs/rka_inted_report_eng.pdf

Department of Foreign Affairs and International Trade, Canada. (2009, September). Best Practice on Managing the Delivery of Canadian Education Marketing. Ottawa: DFAIT. Retrieved from http://www.international.gc.ca/education/assets/pdfs/best_ practices-pratiques_exemplaires_eng.pdf 
Department of Foreign Affairs and International Trade, Canada. ( 2011, October 13). Stronger Ties with World's Best and Brightest in Priority Markets: Goal of International Education Strategy. Retrieved from http://www.international.gc.ca/media_commerce/ comm/news-communiques/2011/300.aspx?lang=eng\&view=d

Department of Foreign Affairs and International Trade, Canada . (2011). Consultation on Canada's International Education Strategy Form. Retrieved from http://www.accc.ca/ $\mathrm{ftp} / \mathrm{misc} / 201111 \_$IEPConsultationForm_EN.pdf

Department of Immigration and Citizenship. (2011, December). Fact Sheet Government Response to the Knight Review of the Student Visa Program. Retrieved from http://www.immi.gov.au/students/_pdf/2011-fact-sheet.pdf

de Wit, H. (2002). Internationalization of Higher Education in the United States of America and Europe: A Historical, Comparative, and Conceptual Analysis. Westport: Greenwood Press.

Downer, Alexander. "Engaging the World Through Education.” Australian Education International and Department of Education. Canberra, Australia. 14 October 2003. Retrieved from http://foreignminister.gov.qu./releases/2003/joint_education.html

Gallagher, M. (2002, October). On the cusp-a new phase in the internationalization of Australian education. Notes for discussion at the $16^{\text {th }}$ Australian InternationalEducation Conference, Hobart. Retrieved from http://www.aiec.idp.com/pdf/Gallagher_p.pdf

Galway, A.D. (200o). Going global: Ontario Colleges of Applied Arts and Technology, international student recruitment and the export of education. Toronto, ON: Ontario Institute for Studies in Education, University of Toronto.

Hamrick, J. (1999). Internationalizing higher education institutions: Broadening the approach to institutional change. Paper presented to the Managing Institutional Change and Transformation Project, University of Michigan. Retrieved from http://www. personal.umich.edu/ marvp/facultynetwork/whitepapers/jimhamrick.html

Harman, G. (2004). New Directions in Internationalizing Higher Education: Australia's Development as an Exporter of Higher Education Services. Higher Education Policy, 17, 101-120.

Harman, G. (2005). Internationalization of Australian Higher Education: A Critical Review of Literature and Research. In P. Ninnes and M. Hellsten (Eds.), Internationalizing Higher Education (pp. 119-140). Netherlands: Springer.

Hazelkon, E. (2008). Globalization, Internationalization, and Rankings. Journal of International Higher Education, 53, 6-8.

International Education Advisory Council (2012, April). Discussion Paper for the Development of an International Education Strategy for Australia, Retrieved from https:// aei.gov.au/IEAC2/Consultation\%28IEAC\%29/Documents/InternationalEducation AdvisoryCouncilDiscussionPaper.pdf.

International Policy Research Symposium Post-secondary education policy issues in Canada Proceedings. (2006, May). Retrieved fromhttp://www1.servicecanada.gc.ca/en/ cs/sp/hrsdc/lp/publications/sp-ah-652-05-06/pageo6.shtml 
Knight, J. (2011). Five Myths About Internationalization in post secondary education, International Higher Education, 62(Winter).

Knight, Michael. (2011, June 30). Strategic Review of the Student Visa Program, Australian government. Retrieved from http://www.immi.gov.au/students/_pdf/2011knight-review.pdf

Kremmer, J. (2010, October 13). Australian conference focuses on drop in foreign students. The Chronicle of Higher Education. Retrieved from http://chronicle.com/ section/Home/5

Marginson, S. (2002). Nation-building Universities in a Global Environment: The Case of Australia. Higher Education, 43, 409-428.

Marginson, S. (2009). Is Australia Overdependent on International Students? International Higher Education, 54, 10-12.

Marginson, S. (2011). International Education in Australia: A long way down. International Higher Education, 62, 20-21.

Marginson,S.,Nyland,C.,Sawir,E., andForbes-Mewett,H.(2010).InternationalStudent Security, Cambridge: Cambridge University Press.

Marshall, N. (1991). Intergovernmental Managerialism: Appropriating the Universities," In Discussion Papers, No. 10. Canberra: Australian National University, Federalism Research Centre.

Mathews, J. (2002). International Education and Internationalisation are not the same as Globalisation: Emerging Issues for Secondary Schools. Journal of Studies in International Education, 6(4), 369-390.

McBurnie, G., \& Ziguras, C. (2003). Remaking the world in our own image: Australia's efforts to liberalize trade in educational services. Australian Journal of Education, 47, 217-218.

McGuinty, D. (2010, March 8). Open Ontario Plan. Speech from the Throne. Retrieved from http://www.premier.gov.on.ca/news/event.php?ItemID=11282\&Lang=EN

Meek, V. Lynn. (2011) The Australian experience of internationalizing higher education. Presentation at the OCUFA conference, "The Race to Globalize Higher Education in Canada", January 21-22, 2011, Torontohttp://www.ocufa.on.ca/conferences.conf2011.gk

National Archives of Canada, Government Archives Division, Records of the Department of External Affairs. (1984, January 20). RG 25, Some Questions of BalanceRecommendation Concerning External Affairs. Vol. 15946, File 55-1-1, acc. no. 10855.

Nelson, B. (2003). Engaging the world through education: ministerial statement on the internationalization of Australian education and training. Canberra: Department of Education, Science and Training.

Nyaland, C., Forbes-Mewett, H., \& Marginson, S. (2010). The International Student Safety Debate: Moving Beyond Denial. Higher Education Research and Development, 29(1), 89-101. 
Oliver, A. (2010, June 22). AEI: Educational diplomacy scapegoat? The Interpreter. Retrieved from http://www.lowyinterpreter.org/post/2010/06/22/AEI-educationaldiplomacy-scapegoat.aspx

Owram, D. (2010, March 8). The international student and the Canadian university: Part 1. University Affairs. Retrieved from http://www.universityaffairs.ca/default.aspx

Phillimore, J., \& Koshy, P. (2010). The Economic Implications of Fewer International Higher Education Students in Australia: Final Report. Australian Technology Network of Universities.

Pratt, Cranford. (Ed.). (1996). Canadian International Development Assistant Policies: An Appraisal. Quebec: McGill/Queen's University Press.

Rae, B. (2005). Ontario: A Leader in Learning - Report and Recommendations. Toronto:Queen's Printer.

Sheffield, E., Campbell, D., Holmes, J., Kymlicka, B., \& Whitelaw, J. (1978). Systems of Higher Education: Canada. New York: International Council for Educational Development.

Shute, J. (1999). From here to there and back again: International outreach in the Canadian university. In S. L. Bond \& J. P. Lemasson (Eds.), A New World of Knowledge. Canadian Universities and Globalization (pp. 21-44). Ottawa: IDRC. Available online: http://www.idrc.ca/en/ev-9400-201-1-DO_TOPIC.html

Sidhu, R. K. (2006). Universities and Globalization: To Market, To Market. New Jersey: Routledge.

Smart, D., \& Ang, G. (1996, December). The Internationalization of Australian Higher Education. International Higher Education, 6, 4-6. Retrieved from http://www.bc.edu/ bc_org/avp/soe/cihe/newsletter/Newso6/text2.html

Steenkamp, P. (2008). The Development of Ontario's Internationalization Strategy. Canadian e-Magazine of International Education, 1(3). Retrieved from http://emagined. appso1.yorku.ca/internationalization-policy-and-strategy/the-development-of-ontariosinternationalization-strategy/

Symons, T.H.B., \& Page, J.E. (1984). To Know Ourselves: The Report of the Commission on Canadian Studies: Vol. 3. Some Questions of Balance: Human Resources, Higher Education and Canadian Studies. Ottawa: Association of Universities and Colleges of Canada.

Tamburri, R. (2008, February). Canada works on a brand for postsecondary education. In University Affairs. Retrieved from http://www.universityaffairs.ca/issues/2008/ february/canada_brand_o1.html

Trilokekar, Roopa. (2007). Federalism, Foreign Policy and the Internationalization of Higher Education: A Case Study of the Department of Foreign Affairs (FAC), Canada (Unpublished doctoral dissertation). University of Toronto, Toronto.

van der Wende, M. C. (2001). Internationalisation policies: about new trends and contrasting paradigms. Higher Education Policy, 14, 249-259. 
Victorian Auditor-General. (2009). International Students: risks and responsibilities of Universities. Retrieved from http://download.audit.vic.gov.au/files/20090624_ international_students_background.pdf

\section{Contact Information}

Roopa Desai Trilokekar

Faculty of Education

York University

4700 Keele Street

Toronto, ON M3 $\mathrm{J}_{1} \mathrm{P}_{3}$ Canada

roopat@edu.yorku.ca

Roopa Desai Trilokekar is an Associate Professor in the Faculty of Education, York University with research interests in international and intercultural education, federal government policy on internationalization, international education as soft power, and federalism and higher education policy. She is currently part of a research team on a Social Sciences and Humanities Research Council General Research project titled, "Making Policy in Postsecondary Education" and has completed a major study of the Government of Canada's role in internationalization and edited a book titled Canada's Universities Go Global (with Dr. Adrian Shubert, York University, and Dr. Glen Jones, University of Toronto).

Zainab Kizilbash is a PhD Candidate in the Faculty of Education, York University. Her areas of study are the internationalization of higher education and teacher professional development. She has completed internships at WorldTeach, based at The Center for International Development, Harvard University, and the University of the Middle East Project's Teacher Education Institute-an intellectual, cultural and professional exchange program for secondary teachers from the Middle Eastern and North African region. She has also worked with Education Beyond Borders running teacher professional development workshops and promoting student centered learning in rural Tanzania. 